\title{
Optimizing Organoleptic Properties of Drinking Yoghurt Incorporated with Modified Kithul (Caryota urens) Flour as a Stabilizer and Evaluating Its Quality during Storage
}

\author{
J.A.A.C. Wijesinghe $e^{1,2^{*}}$, I. Wickramasinghe ${ }^{1}$ and K.H. Saranandha ${ }^{2}$ \\ ${ }^{1}$ Department of Food Science and Technology, Faculty of Applied Sciences, University of Sri \\ Jayewardenepura, Nugegoda, Sri Lanka \\ ${ }^{2}$ Department of Biosystems Engineering, Faculty of Agriculture and Plantation Management, \\ Wayamba University of Sri Lanka, Makandura, Gonawala, Sri Lanka
}

Date Received 15-10-2018

Date Accepted: 02-11-2018

\begin{abstract}
The property of hydration which may function to provide water control by thickening and gelling is the special feature of the kithul flour. This property was used for drinking yoghurt to improve the texture which could be used as an alternative stabilizer for vegetarians. With view this intention this study was focused to improve the recipe for drinking yoghurt with suitable concentration which combined with a better process. Further it was aimed to make appropriate hydration and suitable flour concentration $(0.5 \%$ and $1 \%)$ which gain most agreeable condition on textural and sensory characteristics of final drinking yoghurt product. Physicochemical and sensory attributes for different periods of time (initial, $7^{\text {th }}$ and $14^{\text {th }}$ days) of developed formulation were analyzed. it is concluded that $1 \%$ of pre-gelatinized $\left(75^{\circ} \mathrm{C}\right.$ for 5 minutes) modified kithul flour (Caryota urens) with process for 24 hours refrigeration condition was selected as the best process to maintain most preferable texture condition for drinking yoghurt. Finally, it is also recorded that developed drinking yoghurt could be stored up to 7 days with $242 \mathrm{ppm}$ of potassium sorbate at $4^{\circ}$ C storage.
\end{abstract}

Keywords: drinking yoghurt, kithul flour, modified starch, stabilizer

\section{Introduction}

Drinking yoghurt is considered as a low viscosity stirred yoghurt, which could be consumed rather than a drink. Hence it just for the taste and refreshing drink which can be positioned as breakfast beverage, a sport or wellness energizer or snack to fill the gap between meals and a digestive aid (Tamime and Robinson, 1985; McClements, 2004). Drinking yoghurt is highly customer oriented which is able to meet key product demands as health, enjoyment and combined with mobility. Current performance-oriented society has created lesser time for personal requirements, hence people used to consume instant food which is grabbed on the way to the next

${ }^{*}$ Correspondence: jaacwijesinghe@wyb.ac.lk

(c) University of Sri Jayewardenepura 
appointment. Although they try to get maximum energy and nutrition by that random healthy food choices (Lobato-Calleros et al., 2004).

As in many foods, texture plays key role that exhibits the quality of yoghurt (Gonçalvez et al, 2005, Crion et al., 2012). The most important factors to affect on the yoghurt texture are variations of apparent viscosity and the occurrence of syneresis (Kroger, 1975). Thickeners, stabilizer and gelling agent are generally used in food industry to improve textural properties. Thickeners and stabilizers are used in yoghurt production to afford an appropriate texture by improving consistency increasing its viscosity, improve its mouth feel and reduce syneresis. Syneresis is defined as the shrinkage of gel. This occurs parallel with whey separation which leads to instability of the gel network (Renata et al., 2006; Sahan et al., 2008) and cause to number of negative impacts, such as microbiological infection of the product, loss of the nutritious value, altered texture by break downing of the gel structure. Hence resistance in syneresis is directly combined with better quality of yoghurt. This can be achieved by addition of some ingredients such as dried dairy ingredients, modified starches which leads to increase the density of the protein matrix in the gel microstructure which causes to reduction of syneresis in yoghurt ( $\mathrm{Li}$ and Guo, 2006).

Gelatin and starch are two of the most frequently used thickeners in dairy industry (Walstra et al., 1999). In fact, milk-based proteins, skimmed milk powder, whey proteins and caseins are regularly used to improve viscosity and stability of the yoghurt. Although starch is an economical substitution than these milk based additives (Okoth et al., 2011), which follows the simple processing steps than other hydrocolloids (FOSS, 2000). It can be made in conjunction with dairy ingredients or on their own to modify the rheological properties with different starches various concentrations for appropriate rates of viscosity (Keogh and O'Kennedy, 1998).

Yoghurt rheological characterisation which is essential for product and process development can be done by either instrumental or sensory measurements (Benezech and Maingonnat, 1994). Different sensory attributes shows the textual properties, such as firmness, creaminess, viscosity, mouthfeel and syneresis (Muir and Hunter 1992; Gámbaro, 2002). Further apparent viscosity has a direct correlation with concentration of thickening agent, due to its ability of binding with free water which leads to increase the viscosity (Sahan et al., 2008).

Consumer preference of both yoghurt and drinking yoghurt depends on acidity (sourness), aroma perceptions and textural properties of the product (Beal et al., 1999). Taste and aroma of yoghurt are generally attributed to acetaldehyde produced by L. bulgaricusand S. thermophiles from threonine (Marschall and Cole, 1983).

Adding of suitable preservatives is a method to expand the shelf life of many food products. Most suitable and available preservative in yoghurt industry is potassium/sodium sorbates which is a chemical food preservative. It is generally recognised as safe (GRAS) for use in foods under regulations of FDA (FDA. 2013a) and codex standards (Codex Stan 243-2003). According to Hamdan et al. (1971) sorbates retarded the growth of yoghurt cultures and hence decreased the rate of acid production during fermentation study conducted in laboratory. 
The purpose of these experiments was to examine the influence of modified kithul flour as a stabiliser on the properties of drinking yoghurt. Proximate and chemical composition, viscosity, sensory evaluation and shelf life studies were done with control sample. Microbial analysis, $\mathrm{pH}$ and syneresis were measured during storage at $4^{\circ} \mathrm{C}$ for initial, $7^{\text {th }}$ and $14^{\text {th }}$ days after preparation.

\section{Materials and methods}

\subsection{Yoghurt production raw materials}

The fresh cow's milk (milk fat 3.5\%, protein 3.4\%, carbohydrate $4.8 \%$ and $\mathrm{pH}$ 6.6-6.7) of acceptable organoleptic and microbial quality was obtained from a reputed local supplier. Sucrose, non-fat milk powder used were obtained from a local market in a Colombo, Sri Lanka. The starter culture used was obtained from Christian Hansen, German (STI 12) through a reputed agent in Colombo, Sri Lanka. This is a thermophillic yoghurt starter culture with Streptococcus thermophiles and Lactobacillus bulgaricus microorganisms.

\subsection{Flour sample collection and modification}

Freshly prepared kithul flour (RW) samples were used for the modifications given in sections 2.2.1-2.2.3 and all samples were sifted through a $355 \mu \mathrm{m}$ sieve before further analysis.

Effect of pre-gelatinisation modifications of kithul flour on quality of yoghurt

Pre-gelatinised modification was done with slight modification of method described by Knight, 1969. A 1:1 flour solution (100 g flour for $100 \mathrm{ml}$ deionised water) was incubated at $75^{\circ} \mathrm{C}$ for 5 minutes. Gelatinized flour was dried in a hot air dryer at $40^{\circ} \mathrm{C}$ till moisture level dropped to $10 \%$ to $15 \%$ (Knight, 1969).

\subsection{Process for production of yoghurt Culture preparation}

Daughter culture was made from UHT treated fresh milk and produced by Ambewela farm, Sri Lanka. The milk was heated to $45^{\circ} \mathrm{C}$ and inoculated with STI 12 yogurt culture (50 U in 4001 of milk) according to the producer's recommendation (Chr-Hansen, 2015). Samples were incubated to $43^{\circ} \mathrm{C}$ for $6 \mathrm{~h}$ and $30 \mathrm{~min}$. The fermentation was stopped when the $\mathrm{pH}$ reached 4.6. The set yoghurt samples with compact coagulum were afterwards cooled and stored at $4^{\circ} \mathrm{C}$.

\section{Process}

The modified flour according to the recipe and fresh milk were mixed prior to addition of other ingredients according to the mentioned amounts in Table.1. The mixture was aged at $5^{\circ} \mathrm{C}$ overnight to allow for cooling. Then other ingredients were mixed with cooled milk and flour mixture.

The samples were then pasteurized at $90^{\circ} \mathrm{C}$ for 30 minutes in a boiling pan. The milk was then cooled to $45^{\circ} \mathrm{C}$ and inoculated with $2 \%$ prepared daughter culture. It was stirred for about 30 seconds for complete dissolution and equal distribution of the culture granules in the milk. The milk was incubated at $45^{\circ} \mathrm{C}$ for 5 hours until a firm curd was formed at the top and a $\mathrm{pH}$ of 4.1 4.4 was obtained. This was then aged at $5^{\circ} \mathrm{C}$ overnight to allow for cooling. The curd was broken by swirling 40 times with a hand stirrer to form a smooth homogeneous product. It was then stored under refrigeration at a temperature of $4^{\circ} \mathrm{C}$ for further analysis. 
Table 1: Formulation of new yoghurt recipe with modified starch.

\begin{tabular}{|c|c|c|}
\hline Ingredient & Sample KDY & Sample CDY \\
\hline Fresh Milk & $1000 \mathrm{ml}$ & $1000 \mathrm{ml}$ \\
\hline Non-fat milk powder $(1 \% \mathrm{~g} / \mathrm{v})$ & $10 \mathrm{~g}$ & $10 \mathrm{~g}$ \\
\hline Type of stabilizer & $\begin{array}{l}\text { Modified Kithul } \\
\text { flour }\end{array}$ & Gelatin. \\
\hline $\begin{array}{l}\text { Amount of stabilizer }(1 \% \mathrm{~g} / \mathrm{v}) \\
\text { (According to the SLS } 824: 1989)\end{array}$ & $10 \mathrm{~g}$ & $10 \mathrm{~g}$ \\
\hline $\begin{array}{l}\text { Amount of daughter Culture (prepared according to } \\
2.4 .1(2 \% \mathrm{~g} / \mathrm{v})\end{array}$ & $20 \mathrm{~g}$ & $20 \mathrm{~g}$ \\
\hline Sugar $(20 \% \mathrm{~g} / \mathrm{v})$ & $200 \mathrm{~g}$ & $200 \mathrm{~g}$ \\
\hline $\begin{array}{l}\text { Potassium sorbate ( } 242 \mathrm{ppm}) \text { (permitted preservative } \\
\text { by SLS 824:1989 and Codex Stan 243-2003) }\end{array}$ & $0.3 \mathrm{~g}$ & $0.3 \mathrm{~g}$ \\
\hline
\end{tabular}

\subsection{Analysis}

All yoghurt samples were subjected to analysis of proximate composition, $\mathrm{pH}$, syneresis, viscosity, sensory properties and microbial parameters according to the procedures described below.

\section{Proximate analysis}

Total nitrogen was measured by micro-Kjeldahl method (AOAC, 1990). Protein was calculated as Nx5.38. Fat was determined by the Gerber method (Bradly et al., 1992). Ash content was determined by dry ashing of the samples for $24 \mathrm{~h}$ at $550^{\circ} \mathrm{C}$. Moisture content was determined by drying samples overnight at $105^{\circ} \mathrm{C}$ (AOAC, 1990). Crude fibre content was determined according to the acid/alkali digestion method of AOAC (1990). Analyses were performed in triplicates.

\section{Determination of $p H$ of the yoghurts}

The determination of $\mathrm{pH}$ was done according to the method described by the Adolfo Lutz Institute (Chaves, 2012) through direct reading with a digital pH meter (Hanna pH meter No. 211) using a $10 \mathrm{~mL}$ of yoghurt sample from each experimental unit.

\section{Syneresis of yoghurt}

Degree of syneresis, expressed as proportion of free whey, was measured by a small modification of method used by Al-Kadamany et al, (2003). A $10 \mathrm{~g}$ sample of drinking yoghurt was placed on a filter paper resting on the top of a funnel. After $10 \mathrm{~min}$ of drainage in vacuum condition, the quantity of remained fruit yoghurt was weighted and syneresis was calculated using equation 1 .

Free whey $(g / 100 \mathrm{~g})=\underline{(\text { weight of initial sample }- \text { weight of sample after filtration })} * 100$

\section{Weight of initial sample}


Syneresis was measured during $1^{\text {st }}, 7^{\text {th }}$ and $14^{\text {th }}$ day. The measurements were made in triplicate for each yogurt sample to minimise errors.

\section{Determination of total titratable acidity (TTA)}

This was determined by the method described by AOAC (2005). The sample was dissolved in distilled water and mixed thoroughly. $1 \mathrm{ml}$ of phenolphthalein indicator was introduced into 10 $\mathrm{ml}$ of the mixed solution. It was titrated against standard sodium hydroxide solution until pink colour persisted for about 10-15 seconds for complete neutralisation.

\section{Sensory evaluation}

The sensory evaluation of yoghurt was done by participants using a seven-point scale ( 7 for 'like extremely' down to 1 for 'dislike extremely') to score each attribute (Owni, 2012). Thirty panellist were selected among the faculty, staff, and students of the Department of Food Science and Technology, University of Sri Jayewardenepura. The panellists were given a hedonic questionnaire to test taste, texture, colour, flavour and overall acceptability of coded samples of drinking yoghurt with gelatine as a control and drinking yoghurt with modified kithul flour.

\section{Microbiological analysis}

Microbiological analysis of prepared yoghurt samples included determination of total viable count, total yeast and mold count in freshly prepared and in 7 and 14 days of cold storage at $4^{\circ} \mathrm{C}$ according to the "Sri Lankan Standard for fermented milk products: part 2-yoghurt" by Sri Lanka Standard Institution (SLS 824:part 2 :1989).

Ten grams of drinking yoghurt samples were homogenised using vortex (Type NM 110, Ankara, Turkey) stirrer with $90 \mathrm{ml}$ sterile peptone water to obtain a $10^{-1}$ dilution. Further a tenfold serial dilution was made using the same diluents till a dilution of $10^{-6}$ was obtained. Aliquot of $(0.1$ $\mathrm{ml}$ ) suitable dilution was spread plated in triplicates onto prepared, sterile and dried petri dishes of suitable media for the enumeration of different organisms. The total number of viable microbes per gram of yoghurts was obtained by multiplying the number of colony forming units (CFU) on the plate with respective dilution factor and then was converted into logarithmic form. Plate count Agar (PCA) was used for total viable count enumeration. Potato dextrose agar (PDA) was used for determining yeasts and molds. Experiments were conducted in triplicates.

\subsection{Statistical analysis}

Results were analysed using one-way analysis of variance (ANOVA) at 0.05 probability level using MINITAB software package (version 17 for Windows).

\section{Results and discussion}

Prepared drinking yogurt with modified kithul flour (KDY) and controlled sample with gelatin (CDY) were analysed for proximate composition and chemical parameters to identify the significant differences (Table 2).

Evaluation of proximate composition is essential being the composition of foods influenced on their physical, nutritional, sensory and shelf characteristics considerably (Prodaniuc, 2009; El 
Bakri and Zubeir, 2009). There is no standard published for drinking yoghurt in Sri Lanka. Hence Sri Lanka Standard 824: part 2:1989 specification for fermented milk products is used in order to Identity and meet the requirements for drinking yoghurt. The protein content of CDY $(4.14 \%)$ was significantly higher than KDY $(3.46 \%)$ which was a newly developed product. Reason is very clear as CDY has added gelatin, which is with animal protein as a stabilizer while modified Kithul flour was used for KDY. However, these values were relatively comparable to the $3.5 \%$ protein content of yoghurt reported by Early, (1998).

According to the SLS 824:1989, the regular yoghurt need to be contained a minimum of 8.25 percent milk solids not fat and 3.25 percent milk fat. Treatment KDY fulfil the standard requirement of fat with $3.55 \%$ though control sample showed little bit lesser fat content (3.01\%).Fat plays a critical role to improve the consistency of yoghurt body. However, health conscious current society looking for foods with low fat due to fat provide twice as much energy as with the same quantity of carbohydrate and protein (Ehirim and Onyeneke, 2013).

Table 2: Variation of the proximate and chemical analysis of KDY and CDY Drinking yoghurt samples.

\begin{tabular}{lll}
\hline Parameter & KDY & CDY \\
\hline Protein*** & $3.46 \pm 0.12^{\mathrm{b}}$ & $4.14 \pm 0.04^{\mathrm{a}}$ \\
Fat & $3.55 \pm 0.26^{\mathrm{a}}$ & $3.01 \pm 0.18^{\mathrm{b}}$ \\
Crude Fiber & $0.18 \pm 0.03^{\mathrm{a}}$ & $0.06 \pm 0.01^{\mathrm{b}}$ \\
Ash & $0.36 \pm 0.21^{\mathrm{b}}$ & $0.72 \pm 0.05^{\mathrm{a}}$ \\
Moisture & $68.67 \pm 0.57^{\mathrm{b}}$ & $69.33 \pm 0.57^{\mathrm{a}}$ \\
Solid non- fat (SNF) & $9.83 \pm 1.15^{\mathrm{a}}$ & $7.33 \pm 0.58^{\mathrm{b}}$ \\
Titratable acidity & $0.06 \pm 0.00^{\mathrm{b}}$ & $0.07 \pm 0.00^{\mathrm{a}}$ \\
\hline
\end{tabular}

KDY=kithul drinking yoghurt; $\mathrm{CDY}=$ control drinking yoghurt

Data are the average of three repetitions \pm standard deviation. The values in a raw followed by the same letter are not statically different at a significance level of 5\%.

The total solids not-fat of the kithul drinking yoghurt (KDY) was 9.83, which is accordance with SLS requirement while control sample $(\mathrm{CDY}=7.33)$ did not fulfill the above requirement. The standard for total solids not-fat in the USA is $8.25 \%$ and $8.50 \%$ in UK and Australia respectively (Igbabul et al., 2014). In order to achieve the appropriate texture and viscosity of the final product this value could be raised to approximately 12-15\% (Early, 1998).

The crude fiber of the samples showed $0.18 \%$ in KDY sample which had significantly $(\mathrm{p}<0.05)$ higher than CDY $(0.06 \%)$ due to kithul flour is rich in crude fiber which was used in KDY. According to Schneeman (2002) the crude fiber contributes to the health of the gastrointestinal system and metabolic system in man.

The control sample contained higher ash content (0.72) than KDY (0.36) significantly $(\mathrm{P}<0.05)$. The ash value is an indicator of mineral content, which is necessary for specially bone and teeth development (Trachoo and Mistry, 1998). 
Moisture content of the drinking yoghurt samples were $68.67 \%$ for KDY and $69.33 \%$ for CDY. Kithul drinking yoghurt showed lesser moisture content than control sample. However, both samples indicated better value, which is corresponded with the moisture content reported by Ahmad (1994) who stated that the maximum moisture content of yoghurt should be $84 \%$. Further he explained much water in yoghurt makes it less viscous, called "watery texture", which could be badly affected on texture and mouth feel. However, moisture contents of the control yoghurt samples also showed lower value than the moisture content of most commercial yoghurts (80$86 \%$ ). In this study used gelatin level was $1 \%$ to comparable with used amount of modified Kithul flour for KDY sample. However, generally $0.4-0.6 \%$ is using in yoghurt industry to protect the palatability of a natural yoghurt gel (Lucey, 2002). Sample CDY was prepared with high gelatin content $(1 \% \mathrm{w} / \mathrm{V})$ might be the reason for considerable low moisture content in control sample than commercial yoghurts.

Formulated Drinking yoghurt with Kithul flour and control samples were subjected to shelf life studies with respect to $\mathrm{pH}$ value, Syneresis and Microbial analysis (Table 3 and 5).

Table 3: Variation of the Syneresis and $\mathrm{pH}$ value of Drinking yoghurt samples during the storage period.

\begin{tabular}{|c|c|c|c|c|c|c|}
\hline \multirow[t]{2}{*}{ Sample } & \multicolumn{3}{|c|}{ Syneresis } & \multicolumn{3}{|c|}{$\mathrm{pH}$} \\
\hline & Initial & $\begin{array}{l}\text { After 7th } \\
\text { day }\end{array}$ & $\begin{array}{l}\text { after14th } \\
\text { day }\end{array}$ & Initial & $\begin{array}{l}\text { After 7th } \\
\text { day }\end{array}$ & $\begin{array}{l}\text { after14th } \\
\text { day }\end{array}$ \\
\hline KDY & $0.0 .0 \pm 0.00^{\mathrm{b}}$ & $1.16 \pm 0.23^{\mathrm{b}}$ & $2.28 \pm 0.27^{b}$ & $4.58 \pm 0.03^{\mathrm{a}}$ & $4.51 \pm 0.04^{\mathrm{a}}$ & $4.45 \pm 0.05^{\mathrm{a}}$ \\
\hline CDY & $3.30 \pm 1.15^{\mathrm{a}}$ & $10.16 \pm 0.23^{\mathrm{a}}$ & $18.97 \pm 0.21^{\mathrm{a}}$ & $4.22 \pm 0.02^{b}$ & $4.16 \pm 0.01^{b}$ & $4.09 \pm 0.01^{b}$ \\
\hline \multicolumn{3}{|c|}{ KDY $=$ Kithul Drinking Yoghurt } & \multicolumn{4}{|c|}{$\mathrm{CDY}=$ Control Drinking Yoghurt } \\
\hline
\end{tabular}

Data are the average of three repetitions \pm standard deviation. The values in a column followed by the same letter are not statically different at a significance level of $5 \%$.

The $\mathrm{pH}$ values of both yoghurt samples were decreased as storage time increased, which would be due to conversion of lactose into lactic acid by Lactic acid bacteria (Kamaruzzaman and Rehman, 2000, Eke et al, 2013). According to the difference between initial and final pH both samples shows same reduction rate as 0.13 . Results revealed that there was no significant affect on lactose conversion. Further KDY samples exhibited the least decreased in $\mathrm{pH}$ (4.45) after 14 days indicating less production to acidity than control sample (4.09) significantly $(\mathrm{p}<0.005)$. The decrement in $\mathrm{pH}$ was accompanied by an increase in the alcoholic aroma and acidic taste of yoghurt samples (Lucey, 2004). Hence there is positive view to least $\mathrm{pH}$ reduction to get consumer attraction more. Other researchers also reported as the fermentation times and requisite acidity level were also not affected by the addition of modified starch while, $\mathrm{pH}$ was within the expected range (Lucey and Singh, 1998; Okoth et al., 2011). However pH of both samples (KDY and CDY) were in line with Donkor et al (2006) who has reported as the $\mathrm{pH}$ of yoghurt required to be a maximum of 4.50 in order to prevent the growth of any pathogenic organisms.

Syneresis showed significant reduction with control samples (Table 3). Initially KDY did not indicate any whey separation. Most probably these results could be due to both modified flour 
as well as used process for yoghurt preparation. The process used for preparation of KDY as the modified flour and fresh milk were mixed prior to addition of other ingredients was aged at $5^{\circ} \mathrm{C}$ overnight to help Starch granules to absorb water (Okoth et al., 2011) as more interconnected network would bind aqueous phase more efficiently. These results agreed with those of Fiszman et al. (1997), Zekai (2003), Gonçalvez et al. (2005), Sahan et al. (2006), Amir Aghdai et al. (2010) and Razmkhahsharabiani (2010) who reported the effects of thickeners on syneresis reduction.

Viscosity refers the strength of the gel resistant to breaking of the structure. Viscosity of yogurt often decreases during mixing due to its shear thickening. Further apparent viscosity has a direct relationship with type and concentration of stabiliser. It was assumed that Stabilisers bind with free water and trap it in casein network thus cause to increase viscosity of sample (Sahan et al., 2006) which helps to decrease Syneresis. However low values of stabiliser formed fewer number of junction points in protein network. Hence there are much more open structure in the samples which would be contribute to texture with lower firmness (Fisezman et al., 1997).

The trend of apparent viscosity of samples contained different amounts of various stabilisers, is shown in Fig 1. The graphs indicate that when use the same amount of stabiliser as gelatin and Modified kithul flour in CDY and KDY respectively showed different viscosity. In CDY sample , $1 \%$ gelatin created much viscous texture even after homogenizing the yoghurt curdle during the process of drinking yoghurt. Same observation has reported by previous studies (Sahan et al., 2008; Fiszman et al., 1997 and Amir Aghdai et al., 2010).

In the case of modified starch granules imbibe water and swell to many times than their original size, resulting in increased viscosity of the texture (Okoth et al., 2011). It is clearly figured out by the behaviour of modified Kithul starch with yoghurt texture. According to Okoth et al. (2011), when starch is used for stabilisation the yoghurt should be given a few days for its viscosity to age and stabilise. It has observed by this study because of aging 24 hours fresh milk and modified Kithul flour gave the better results.

Table 4. Comparison of Sensory properties of formulated final Drinking Yoghurt vs control sample and market sample

\begin{tabular}{|c|c|c|c|c|c|c|c|c|}
\hline 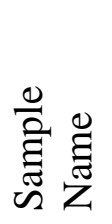 & $\frac{\grave{z}}{0}$ & $\begin{array}{l}\bar{\Xi} \\
\frac{0}{0} \\
\end{array}$ & 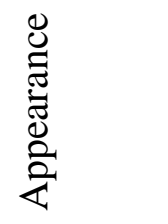 & $\begin{array}{l}\bar{\Xi} \\
\stackrel{\Xi}{\Xi} \\
\bar{I}\end{array}$ & 永 & 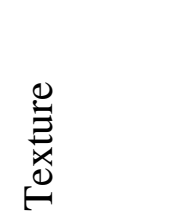 & 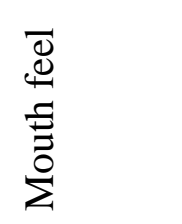 & 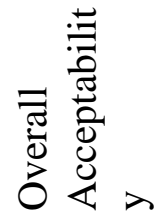 \\
\hline $\mathrm{CDY}$ & $6.27 \pm 0.74^{\mathrm{a}}$ & $5.43 \pm 0.97^{\mathrm{a}}$ & $6.03 \pm 0.89^{\mathrm{a}}$ & $5.23 \pm 1.30^{\mathrm{a}}$ & $5.43 \pm 1.01^{\mathrm{a}}$ & $5.60 \pm 1.28^{\mathrm{ab}}$ & $5.10 \pm 1.56^{\mathrm{b}}$ & $5.63 \pm 1.03^{\mathrm{a}}$ \\
\hline KDY & $4.23 \pm 1.75^{\mathrm{b}}$ & $5.70 \pm 1.12^{\mathrm{a}}$ & $4.63 \pm 1.56^{\mathrm{b}}$ & $5.80 \pm 1.49^{\mathrm{a}}$ & $5.23 \pm 1.45^{\mathrm{a}}$ & $5.67 \pm 1.24^{\mathrm{a}}$ & $6.13 \pm 1.01^{\mathrm{a}}$ & $5.70 \pm 1.21^{\mathrm{a}}$ \\
\hline MDY & $6.20 \pm 0.71^{\mathrm{a}}$ & $5.70 \pm 1.09^{\mathrm{a}}$ & $5.63 \pm 1.16^{\mathrm{a}}$ & $5.60 \pm 1.00^{\mathrm{a}}$ & $5.00 \pm 1.46^{\mathrm{a}}$ & $4.80 \pm 1.56^{\mathrm{b}}$ & $5.07 \pm 1.48^{\mathrm{b}}$ & $5.27 \pm 1.08^{\mathrm{b}}$ \\
\hline
\end{tabular}

Data are the average of three repetitions \pm standard deviation. The values in a column followed by the same letter are not statically different at a significance level of $5 \%$. 
The mean sensory scores of the organoleptic evaluation and acceptability for the different yoghurt samples are shown in Table 4 . The statistical analysis revealed that there were significant differences $(p<0.05)$ among three drinking yoghurt samples in the sensory attributes observed. Sample CDY (control sample) and MDY (Market sample) had significantly $(\mathrm{P}<0.05)$ highest score $(6.27,6.20)$, while sample KDY had the lowest score (4.23) for colour. Because of the colour of Kithul flour being pinkish KDY sample has light off white than normal drinking yoghurt. Rajyalakshmi (2004) reported that the main problem with the kithul flour for the industrial food production is its pinkish colour. Although this colour attribute evident the presence of polyphenols as common plant antioxidant (Weisburger, 1999) which produce health benefits. Total polyphenol content of crude kithul flour ranged from 52\% (Anilakumai and Rajyalakshmi, 2000) to 79\% (Senavirathna et al., 2013).Hence it is very important to promote this new product with natural antioxidant without concern about the colour without adding synthetic colours.

The appearance was influenced by colour-appeal, the panelists showed preference for the lighter colour of sample CDY and MDY than KDY with modified Kithul flour treatment. Flavour, odour, acidity attributes had same preferences among all panelist for three samples. The incorporation of modified kithul flour with drinking yoghurts resulted in better texture and mouthfeel scores. Sample KDY got higher preference of panelists for texture with 5.67 score. It is significantly $(\mathrm{P}<0.05)$ higher than control sample $(\mathrm{CDY}=5.6)$ and market sample (MDY=4.8).Mouthfeel followed the same pattern with highest score (6.13) for Sample KDY, while sample CDY (5.10) and MDY (5.07) had the lower scores. Finally most of the panelist appreciated the sample KDY (5.70) which was attributed addition of new stabilizer (modified kithul flour) considering the overall acceptability. But it not showed significant difference $(\mathrm{P}>0.05)$ with CDY (5.63).However KDY got $66.7 \%$ consideration from the panelists (Figure 1) by ranking as best product among all three samples. Hence there is huge potential to introduce modified Kithul flour as stabilizer in food industry. However required modification could be differ according to the product.

Table 5: Variation of the Microbiological analysis of Kithul Drinking yoghurt (KDY) sample during the storage period.

\begin{tabular}{lcc}
\hline Storage period & Total plate count $(/ \mathrm{g})$ & Yeast and mold count $(/ \mathrm{g})$ \\
\hline Initial & $7.3 \times 10^{4}$ & $7.4 \times 10^{2}$ \\
After 7th day & $2.6 \times 10^{5}$ & $9.5 \times 10^{3}$ \\
After 14th day & $5.9 \times 10^{5}$ & $1.2 \times 10^{3}$ \\
\hline
\end{tabular}

Results are expressed as mean $(n=3)$.

The shelf life of non-sterile dairy products such as yoghurt and fermented milk products, is generally limited to one to three weeks (Salvador and Fiszman, 2004).

Microbial activity is the most critical limitation of the shelf life of food in general which leads to the formation of off-flavors and other undesirable physicochemical changes that simultaneously cause to product failure (Salji et al., 1987; Muir and Banks, 2000). 


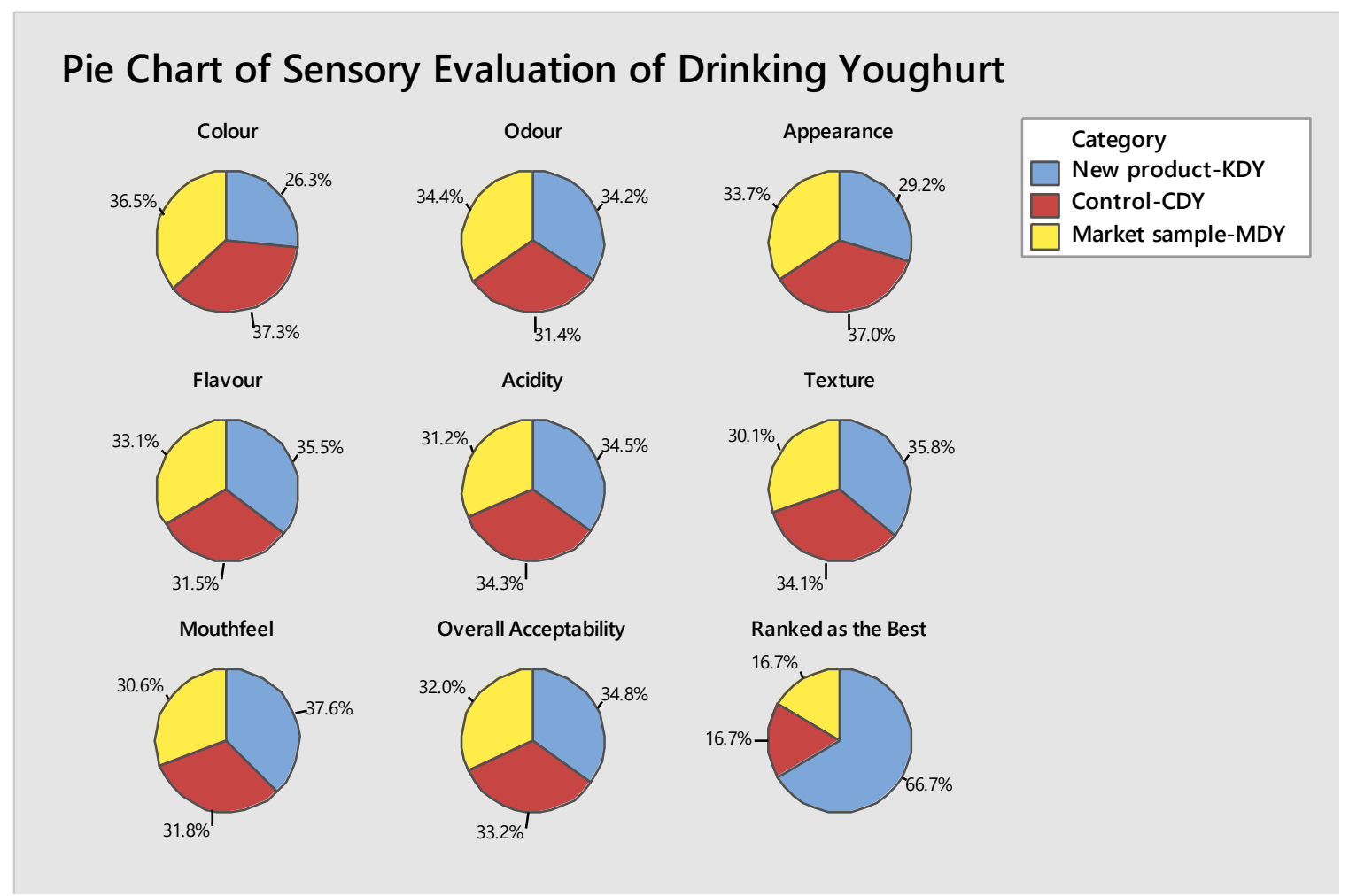

Figure 1 .Comparison of Sensory evaluation results

The results obtained revealed that KDY samples contained at the initial and $14^{\text {th }}$ day, total number of $7.3 \times 10^{4}$ and $5.9 \times 10^{5} \mathrm{~g}^{-1}$ viable cells of bacteria, respectively (Table 5). Initial bacterial count increased significantly $(\mathrm{P} \leq 0.05)$ during storage of both yogurt types. Bacterial count reached its extreme increment at the $7^{\text {th }}$ day, and thereafter slowly increased till $14^{\text {th }}$ day, as $2.6 \times 10^{5}$ and $5.9 \times 10^{5} \mathrm{~g}^{-1}$, respectively. The increment of the acidity which indicated by reduction of $\mathrm{pH}$ of the growth media (Table 3) with the storage time may retard the bacterial growth. These results are in agreement with the findings of Masud et al. (1991).

Yeasts and moulds were increased with increase in the initial $7^{\text {th }}$ day storage time as $7.4 \times 10^{2}$ and $1.2 \times 10^{3} \mathrm{~g}^{-1}$ respectively. An increment of acidity (Table 3) and reduction of oxygen during fermentation process may offer proper conditions for growth of yeasts and molds. These two are generally linked with traditional fermented dairy products as contamination by yeasts and moulds (Beukes et al., 2001; Isono et al., 2001, Dardashti et al., 2001). These two could also come from the environment where proper air control system is not in place. In this study potassium sorbate was used as preservative at 300ppm level. However, it could be increased till $1000 \mathrm{ppm}$ according to the Codex Standard (2003). Although Tamime and Robinson (1999) have reported that potassium sorbate does not reduce the actual number of yeast and molds in the product, but merely inhibit their activity. 


\section{Conclusion}

It is concluded that modified kithul (Caryota urens) flour gave better results for syneresis, viscosity and for all sensory attributes except for colour.

It also observed that drinking yoghurt with modified kithul flour can be stored up to 7 days with minimum level of preservative as $242 \mathrm{ppm}$ of potassium sorbate, when kept at $4^{\circ} \mathrm{C}$ by giving proper storage and especially packaging condition. The drive to extend shelf life stems from increased distribution center demands due to consolidation of manufacturing facilities.

\section{Acknowledgement}

Authors thank the University of Sri Jayewardenepura, Sri Lanka for providing financial assistance for this study (Grant No: ASP/06/RE/SCI/2012/04).

\section{References}

Ahmad J. 1994. Quality characteristics of plain yoghurt made from standardized Buffalo milk. M.Sc Thesis University of Agriculture, Faisalabad.

Amir R.M., Anjum F.M., Khan M.I., Pasha M.R.K.I., Nadeem M. 2013. Application of Fourier Transform infrared (FTIR) Spectroscopy in Foods. Journal of Food Science and Technology, 50(5): 1018-23.

Anilakumai B., Rajyalakshmi P. 2000. Qualitative aspects, product suitability and in vitro starch digestibility of caryota palm sago-An uncommon food tribals. Journal of Food Science and Technology, 37(1): 75-78.

AOAC. 1990 Official methods of analysis. Association of Official and Analytical Chemists Washington DC.

AOAC. 2005. Official Methods of Analysis. Association of Official and Analytical Chemists Washington DC.

Beal C., Skokanova J., Latrill E., Martin N., Corrieu G. 1999. Combined effects of culture conditions and storage time on acidification and viscosity of stirred yogurt. Journal of Dairy Science, 82: 673-681.

Benezech T., Maingonnat J.F. 1994; Characterization of the rheological properties of yogurt: A review. Journal of Food Engineering, 21: 447-472.

Beukes E.M., Bester, B.H., Mostert J.F. 2001. The microbiology of South African traditional fermented milk. International Journal of Food Microbiology, 63: 189-197.

Codex Stan 243-2003, Codex standard for fermented milks, adopted in 2003. Revision 2008, 2010.

Crion C.I.E., Gee V.L., Kelly A.L., Auty M.A.E. 2012. Modifying the microstructure of low-fat yoghurt by microfluidisation of milk at different pressures to enhance rheological and sensory properties. Food Chemistry, 130: 510-519.

Dankor N.O., Henrikson A., Vasiljevie T., Shah N. 2006. Effect of acidification on the activity of probiotics in yoghurt during cold storage. International Dairy Journal, 16:1181-1189.

Dardashti A.D., Afshin A., Saeed B., Grce M., Pigac J., Marsa V. 2001. Study of coliform, yeast and mold contamination of yogurt in Ghaemshahr in lran. Periodicum Biologorum, 103: 183-186.

Eearly R. 1998. The technology of dairy products (2nd ed). International Thomson publishers. 
Ehirim F.N., Onyeneke E.N. 2013. Physicochemical and organoleptic properties of yoghurt manufactured with cow milk and goat milk. Part-I: Natural and Applied Sciences, 4(4) 245 252.

El Bakri J.M., Zubeir E.M. 2009. Chemical and microbiological evaluation of plain and fruit yoghurt in Khartoum state Sudan. International Journal of Dairy Science, 4(1): 1-7.

FDA. 2013. Yogurt. 21 CFR 131.200, Code of Federal Regulations. U.S. Dept. of Health and Human Services, Washington, DC.

Fiszman S.M., Lluch M.A., Salvador A. 1999. Effect of addition of gelatin on microstructure of acidic milk gels and yoghurt and on their rheological properties. International Dairy Journal, 9: 895-901.

Gámbaro A. 2002. Aplicación de nuevas methodologíassensoriales a un estudio integral de yogur. Tese (Doutorado) - Facultad de Química, Universidad de la República, Uruguay.

Gonçalvez D., Pérez C., Reolon G., Segura N., Lema P., Gámbaro A., Ares G., Varela P. Effect of thickeners on the texture of stirred yogurt. Alim. Nutr., Araraquara, ISSN 0103-4235. 16(3): 207-211.

Hamdan I.Y., Deane D.D., Kunsman J.E. 1971. Effect of potassium sorbate on yogurt cultures. Journal of Milk Food Technology, 34: 307-311.

Igbabul B., Shember J., Amove J. 2014) Physicochemical, microbiological and sensory evaluation of yoghurt sold in Makurdi metropolis. African Journal of Food Science and Technology, 5(6): 129-135.

Isono Y., Shingu I., Shimizu S. 2001. Identification and characteristics of lactic acid bacteria isolated from Maasai fermented milk in northern Tanzania. Bioscience, Biotechnology and Biochemistry, 58: 660-664.

Kamruzzaman M. N., Rehman, M.M. 2002. Shelflife of different types of dahi at room and refrigeration temperature. Pak. J. Nut., 1(6): 234- 237.

Knight J.W. 1969. The Starch Industry. Pergman Press Ltd, Oxford.

Koegh M.K., O'Kenedy B.T. 1998. Rheology of stirred yoghurt as affected by added milk fat, protein and hydrocolloids. Journal of Food Science, 63: 108-112.

Kroger M. 1975. Quality of yogurt. Journal of Dairy Science, 59:(2): 344-350.

Li J., Guo M. 2006. Effects of polymerized whey proteins on consistency and water-holding properties of goat's milk yogurt. Journal of Food Science, 71(1), 34-38.

Lobeto-Calleros C., Martínez-Torrijos O., Sandoval-Castilla O., Pérez-Orozco J.P., Vernon-Carter E.J. 2004. Flow and creep compliance properties of reduced-fat yoghurts containing protein-based fat replacers. International Dairy Journal, 14: 777-782.

Lucey J.A., Singh H. 1998. Formation and physical properties of acid milk gels: a review. Food Research International, 13: 529-542.

Lucey J.A. 2002. Foundation scholar award formation and physical properties of milk protein gels. Journal of Dairy Science, 85: 281-294.

Lucey J.A. 2004. Cultured dairy products: An overview of their gelation and texture properties. International Journal of Dairy Technology, 57(2/3): 77-84.

Marschall V.M., Cole W.M. 1983. Threonine aldolase and alcohol dehydrogenase activities in Lactobacillus bulgaricus and Lactobacillus acidophilus and their contribution to flavor production in fermented milks. Journal of Dairy Research, 50: 375-379.

Masud T., Sultana K., Shah M.A. 1991. Incidence of lactic acid bacteria isolated from indigenous dahi. Australian Journal of Animal Science, 4: 329-331. 
Mc Clements D.J. 2004. Food emulsions: Principles, practices, and techniques (2 ${ }^{\text {nd }}$ ed). Orlando: Taylor \& Francis CRC Press.

Muir D.D., Banks J.M. 2000. Milk and milk products. The stability and shelf-life of food. CRC Press, Boca Raton.

Muir D.D., Hunter, E.A. 1992. Sensory evaluation of fermented milks: vocabulary development and the relations between sensory properties and between acceptability and sensory properties. Journal of Society of Dairy Technology, 45(3): 74-80.

Okoth E.M., Kinyanjui P.K., Kinyuru J.N., Juma F.O. 2011. Effects of substituting skimmed milk powder with modified starch in yoghurt production. JAGST, 13(2): 25-32.

Owni E.O.A.O., Mahgoub M.S.A. 2012. The effect of storage on chemical, microbial and sensory characteristics of goat's milk yoghurt, Journal of Novel Applied Sciences, 1(2): 63-67.

Prodaniuc Natalia. 2009. Study regarding some physicalchemical characteristics of the yoghurt with red beetroot juice. Carpathian Journal of Food Science and Technology, 1(2): 44-49.

Rajyalakshmi P. 2004. Caryota palm sago potential get underutilized natural resource for modern starch industry. Natural Products, 3(3): 144 -149.

Renata B. Magenis, Elane S. Prudencio. 2006. Compositional and physical properties of yogurts manufactured from milk and whey cheese concentrated by ultrafiltration, International Journal of Food Science and Technology, 41: 560-568.

Sahan N., Yasar K., Hayaloglu A.A. 2008. Physical, chemical and flavour quality of non-fat yogurt as affected by a $\beta$-glucanhydrocolloidal composite during storage. Food Hydrocolloids, 22: 1291-1297.

Salji J.P., Saadi, S.R., Mashhadi A. 1987. Shelf life of plain liquid yoghurt manufactured in Saudi Arabia. Journal of Food Protection, 50(2): 123-126.

Salvador A., Fizsman S.M. 2004. Textural and sensory characteristics of whole and skimmed flavored set-type yoghurt during long storage. Journal of Dairy Science, 87: 4033-4041.

Schneeman B.O. 2002. Gastrointestinal physiology and functions. British Journal of Nutrition, 88(2): 159-163.

Senavirathna R.M.I.S.K, Ekanayake S., Jansz E.R., Welihinda J. 2013. Total phenol content and antioxidant potential of traditional breakfast meals of Sri Lanka. Malaysian Journal of Nutrition, 19(2): 243-250.

SLS 824:1989, Part 2. Specifications for fermented milk products, Sri Lanka Standard Institution.

Tamime A.Y., Robinson R.K. 1985. Yoghurt science and technology. Pergamon Press, Oxford.

Trachoo N., Mistry V.V. 1998. Application of ultra- filtered sweet butter milk and sweet butter milk powder in the manufacture of non- fat and low fat yoghurt. Journal of Dairy Science, 81: 774-788.

Vasconcelos C.M., Minim V.P.R., Chaves J.B.P. 2012. Low-calorie yogurt added with yacon flour: Development and physicochemical evaluation. Revista Chilena de Nutricion, 39(3): 65-71.

Walstra P. 1999. Dairy Technology. Marcel Dekker, New York.

Zekai Tarakçi, Erdogan Küçüköner, 2003. Physical, chemical, microbiological and sensory characteristics of some fruit-flavored yoghurt. YYÜ Vet FakDerg, 14(2): 10-14. 